\title{
„Pięćdziesiątnica pogan" w ujęciu Dziejów Apostolskich (Dz 10, 1-11, 18). Casus Korneliusza i jego domu
}

\author{
Krzysztof Pilarczyk \\ Uniwersytet Jagielloński \\ krzysztof.pilarczyk@uj.edu.pl (D) https://orcid.org/0000-0001-9283-1204
}

Dzieje Apostolskie to unicum w zbiorze ksiąg Nowego Testamentu. Tak pod względem genologicznym, jak i treściowym nie mają one ani prekursorów, ani naśladowców w pismach zaliczonych do chrześcijańskiego kanonu ${ }^{1}$. Przy tym dostarczają dość szczególny obraz powstania i rozwoju Kościoła. Oczywiście należy pytać, jaki to obraz - historyczny, mityczny, teologiczny czy teologiczno-polemiczny? W rekonstrukcji tego obrazowania początków Kościoła potrzeba najpierw ukazać autorską koncepcję całej księgi, a następnie przejść do usytuowania w niej fragmentu, który dotyczy interesującego nas chrztu pierwszych pogan (nie-Żydów), czyli do casusu Korneliusza i jego domu, o czym mowa w Dz 10,1-11, 18. Następnie należy prześledzić historię egzegezy wskazanej perykopy, by w końcu podjąć próbę zrozumienia owego opisu w kontekście najnowszych badań nad nowotestamentowymi Lukanami.

\section{Dzieje - pomiędzy mitem a historią}

Struktura literacka Dziejów daje się ująć w siedem części²:

- $\quad$ początek i rozwój Kościoła w Jerozolimie (Dz 1-5);

- napięcia stworzone przez judeochrześcijan hellenistów i prześladowania Kościoła (Dz 6-7);

1 Por. K. Pilarczyk, Literatura wczesnochrześcijańska, [w:] Historia literatury światowej w dziesięciu tomach, t. 1: Starożytność, red. T. Skoczek, Bochnia-Kraków-Warszawa [2003], s. 556-557; B. D. Ehrman, Nowy Testament. Historyczne wprowadzenie do literatury wczesnochrześcijańskiej, przekł. z jęz. ang. S. Tokariew, Warszawa 2014, s. 199-203.

2 Por. F. F. Bruce, Dzieje apostolskie, [w:] Stownik wiedzy biblijnej, red. nauk. B. M. Metzger, M. D. Coogan, konsultacja wyd. pol. W. Chrostowski, konsultacja wersji oryg. B. Geller Nathanson [et al.], przekł. A. Karpowicz [et al.], wyd. 3, Warszawa 1999, s. 128. 
- $\quad$ szerzenie Dobrej Nowiny o Jezusie Chrystusie w Samarii oraz środowiskach pogańskich aż po syryjską Antiochię (Dz 8-12);

- rozwój misji od Antiochii po Cypr i Azję Mniejszą (Dz 13-15);

- rozstrzygnięcia dotyczące prowadzonej misji wśród pogan (Dz 15, 1-16, 5);

- misja Pawła i jego towarzyszy w prowincjach nad Morzem Egejskim (Dz 16, 6-19, 20);

- obszerny epilog Pawłowej działalności (Dz 19, 21-28, 31).

Księga opisuje zatem wybrane epizody z szerzenia Dobrej Nowiny (Ewangelii) począwszy od Jerozolimy, a skończywszy na Rzymie. Kryje się w niej jednak jeszcze inny poziom przekazu, który dokonuje się przy pomocy specyficznego (religijnego) języka ${ }^{3}$. Czytamy w Dziejach o boskich interwencjach przy wyborze następcy apostoła - Macieja, zstępujących na apostołów językach jakby z ognia i mówieniu wieloma językami, licznych uzdrowieniach, wkroczeniu anioła do więzienia i uratowania Piotra, głosie z nieba, wielokrotnych wizjach zawierających boski przekaz, cudownym uratowaniu życia po ukąszeniu węża. Widać, że autor Dziejów podziela obowiązującą w jego środowisku wizję świata, tłumacząc zarazem owe boskie interwencje. Silny akcent pneumatologiczny w kreowaniu tego obrazu prowadzi do konstatacji, że powstanie i rozwój Kościoła jest sprawą przede wszystkim boską, dopiero w drugim rzędzie ludzką, a Duch Święty zapewnia skuteczność głoszonej przez ludzi Ewangelii i żywotność wspólnocie chrześcijańskiejª . Dlatego ta instytucja bosko-ludzka musiała być opisana językiem, który - nie waham się nazwać - mitycznym, aby oddać jej tak pojmowaną istotę.

Sama kompozycja Dziejów jest silnie związana z ujęciem mitycznym, co rzutuje na przedstawianie początków chrześcijaństwa. Z pewnością obecne w tej księdze elementy cudowności wywierały wpływ nie tylko na bezpośrednich

3 Zwraca na to uwagę J. B. Tyson, widząc w opisie Dziejów obraz mityczny, który bliski jest Bultmanowskiej definicji mitu (zob. R. Bultmann, Jesus Christ and Mithology, New York 1958, s. 15; R. T. Ptaszek, Bultmann Rudolf, [w:] Powszechna encyklopedia filozofii, t. 1, Lublin 2000, s. 736). Według niej mitycznym jest każda próba przedstawienia tego, co wieczne (Boskie), jako tego, co doczesne (zanurzone w historii). Por. J. B. Tyson, Acts, Myth, and History, [w:] Acts and Christian Beginnings. The Acts Seminar Report, ed. by D. E. Smith and J. B. Tyson, Salem, Oregon 2013, s. 15-18. Tej kwestii dotyczy także jego obszerniejszy artykuł Acts - A Myth of Christian Origins, „Forum” Third Series 1 (2007) nr 2, s. 171-189, http://www.westarinstitute.org/wp-content/ uploads/2014/05/Forum-12-The-Quest-of-Christian-Origins.pdf (14.01.2017).

4 Por. F. Gryglewicz, Teologia Dziejów Apostolskich, listów katolickich i pism św. Jana Ewangelisty, Lublin 1986, s. 15-16; W. Rakocy, „Będziecie moimi świadkami...” (Dz 1, 8) (Dzieje Apostolskie), [w:] Dzieje Apostolskie. Listy św. Pawła, oprac. A. S. Jasiński [et al.], Warszawa 1997, s. 42-47. 
jej adresatów (drugie i trzecie pokolenie chrześcijan), ale także na kolejne ich generacje. Rola Dziejów w konstruowaniu mitu o powstaniu chrześcijaństwa jest najlepiej widoczna w podstawowych jej tematach, które same w sobie nie są nasycone ową cudownością, co widać w przedstawionej wcześniej strukturze literackiej księgi. Autor Dziejów podkreśla przede wszystkim jednolity charakter ruchu Jezusa ${ }^{5}$. Wprowadza on inspirujące narracje, które dają obraz jedności i harmonii pierwotnej wspólnoty chrześcijańskiej oraz podkreślają w niej znaczenie autorytetu dwunastu apostołów. Czytelnik uczy się przez to, że pod ich przywództwem wspólnota ta radzi sobie nawet ze sporami, łatwo je zażegnując, oraz dokonuje sprawiedliwego podziału dóbr w celu zaspokojenia potrzeb jej członków. W Dziejach wczesna wspólnota Jezusa przeniknięta jest wiarą w Biblię hebrajską, odwołuje się do niej, aby objaśniać nową rzeczywistość Kościoła, oraz okazuje przywiązanie do żydowskich rytów i tradycji, mimo opozycji wobec oficjalnych żydowskich autorytetów. Czytelnik Dziejów uczy się też, że ruch chrześcijański miał swój początek w Jerozolimie pod kierunkiem osób wyznaczonych przez Jezusa, które były świadkami Zmartwychwstałego i to On nakazał im pozostać w Jerozolimie aż do chwili, gdy otrzymają Ducha - moc z wysoka. W tym obrazie pierwotnego chrześcijaństwa obecny jest również Paweł z Tarsu, choć nie należał do Dwunastu, ale związany był mocno z jerozolimskim Kościołem i apostołami oraz za ich przyzwoleniem prowadził misyjną działalność. A przede wszystkim, że chrześcijańscy przywódcy kierowali się w swym działaniu tym, co boskie, i dlatego rozwój Kościoła przebiegał w sposób uporządkowany. Zatem autor Dziejów przyjął mitologiczny kontekst i wpisał go w wiodące tematy, które służyły przedstawieniu początków Kościoła ${ }^{6}$.

Można pytać, czy te początki pierwotnych kościołów mogłyby być opisane inaczej? Alternatywnego ich opisu powinniśmy szukać tylko pośród świadectw chrześcijan żyjących w tym czasie, gdy wydarzenia z nimi związane się rozgrywały. Takich dostarcza w zasadzie jedna osoba - Paweł z Tarsu i pozostałe po nim listy jako źródło pisane do dziejów pierwotnego chrześcijaństwa. One dają nam obraz ruchu Jezusa, który nie był już tak spójny, jak przedstawiają to Dzieje, posiadał różne frakcje i konkurencyjne poglądy, by nie powiedzieć teologie. We wspólnotach Pawłowych zaistniałe problemy nie

5 K. Pilarczyk, Wokót problemu datacji Dziejów Apostolskich, „Wrocławski Przegląd Teologiczny” 23 (2015) nr 2, s. 88.

6 Tamże, s. 88-89. 
były łatwo rozwiązywane. W tych wspólnotach byli apostołowie, a Paweł był jednym z nich. W jego przekazie liczba apostołów (posłańców niosących Dobrą Nowinę o Jezusie) nie była ściśle określona, nie ograniczała się jak u Łukasza do urzędowych świadków (gr. martyres) - Dwunastu, którzy towarzyszyli historycznemu Jezusowi, w końcu niekoniecznie musieli być oni mężczyznami. Chociaż Paweł zna i respektuje dwunastu apostołów, którzy poprzedzają go w wierze, podkreśla jednocześnie w listach swoją niezależność od nich.

Patrząc w Pawłowym kontekście na Dzieje, jeszcze wyraźniej widać mityczność tej księgi, ponieważ ich autor ukazał - chciałoby się powiedzieć - idylliczny portret pierwotnej wspólnoty Jezusa. Jego narracja podporządkowuje podejmowane tematy temu, aby go one wspierały. Jednocześnie jej autor pisze swą księgę, posiadając większy dystans czasowy niż Paweł wobec tego, co opisuje, mając zarazem zupełnie różną perspektywę aniżeli świadkowie początków Kościoła, jak na przykład Apostoł Narodów.

Jeżeli zatem Dzieje Apostolskie są kartą mitu powstania chrześcijaństwa, należy zapytać, jakie mają one znaczenie jako źródło dla badań historycznych? Jakie ma znaczenie zawarty w nich przekaz, w tym ten, który dotyczy kwestii nas interesującej - casusu Korneliusza.

\section{Dz 10,1-11, 18 w strukturze całej księgi oraz jej kompozycja, języki i istota przekazu}

Interesująca nas perykopa przynależy do trzeciej części Dziejów, w której mowa o szerzeniu Dobrej Nowiny o Jezusie Chrystusie w Samarii oraz w środowiskach pogańskich aż po syryjską Antiochię (Dz 8-12). Można w niej wyróżnić pięć epizodów (scen) ${ }^{7}$ :

- wizję Korneliusza (10, 1-8),

- wizję Piotra (9-16),

- opis przybycia posłańców od Korneliusza z Cezarei do Piotra w Jaffie (17-23a),

- $\quad$ wydarzenia w domu Korneliusza (23b-48),

- relację Piotra o chrzcie Korneliusza przed starszyzną jerozolimską i wyjaśnienia dotyczące jego zachowania w Cezarei (11, 1-18).

7 Por. F. Gryglewicz, Egzegeza Dziejów Apostolskich (r. 9-12), [w:] Materiały pomocnicze do wykładów z biblistyki, t. 5, pod red. L. Stachowiaka, R. Rubinkiewicza, Lublin 1982, s. 145. 
Perykopa sprawia wrażenie dość rozwlekłego opowiadania z licznymi powtórzeniami dotyczącymi charakterystyki Korneliusza (10, 1-2. 22. 35), jego wizji i wysłania posłańców do Piotra (10, 3-8. 22. 30-33) oraz wizji Piotra (10, 9-16;11, 5-10). Szereg opisów powtórzonych jest dwukrotnie, jakby autor chciał je szczególnie eksponować. Pewnych analogii można dopatrywać się między nimi a trzykrotnymi opisami nawrócenia Szawła, choć miały one różne znaczenie dla pierwotnego Kościoła.

Język opowiadania jest na wskroś mityczny. Ludzkie doświadczenia Korneliusza i Piotra objaśniane są interwencją anioła $(10,7$; 11, 13) nazwanego świętym $(10,22)$ lub Bożym aniołem $(10,3)$, który wyglądał jak „ktoś w jaśniejącej szacie” (10, 30) i komu przydany był tytuł „Pan” (gr. Kyrios). Widzenie Piotra miało miejsce w czasie ekstazy (10, 11; 11, 5). Mówi się przy jego przedstawianiu o niebie otwartym $(10,11)$, o naczyniu z nieba opuszczanym i do niego zabieranym (10, 11. 16; 11, 5. 10), głosie z nieba (10, 13;11, 7. 9), Piotrze zwracającym się do tego głosu jako do „Pana” (gr. Kyrios; 10, 14; 11, 8), poleceniu wydawanym przez anioła Korneliuszowi, nakazowi danemu przez Ducha Świętego, aby Piotr poszedł do Korneliusza ${ }^{8}$.

Istota przekazu zawartego w perykopie dotyczy pogan, którym - ku zaskoczeniu wszystkich - „został udzielony dar Ducha Świętego” (10, 45), co apostołowie i wierni z Judei zrozumieli jako „przyjęcie przez pogan słowa Bożego” $(11,1)$ oraz „udzielenie poganom przez Boga pokuty [nawrócenia]” $(11,18)^{9}$. Ważne jest w tym przekazie utrwalonym przez Łukasza, iż odnosi on te stwierdzenia nie personalnie do Korneliusza, lecz ogólnie do wszystkich pogan: wyprowadza z tego wniosek, że „żadnego człowieka” nie należy uważać za nieczystego (10, 28), że Jezus jest „sędzią żywych i umarłych” (10, 42), że „każdy, kto wierzy” w Jezusa, otrzyma odpuszczenie grzechów $(10,43)$; a także mówi o „wszystkich” zwierzętach jako czystych $(10,12)^{10}$.

Ten przełom, jaki dokonał się w Kościele przez włączenie do niego pogan, w ujęciu Łukasza przypisywany jest samemu Bogu. Piotr, nawiązując do swego widzenia, wprost mówi do Korneliusza, że Bóg mu „pokazał”, że nie ma już różnicy pomiędzy ludźmi i że wszyscy mają do Niego jednakowy przystęp. Bóg

8 Por. Acts and Christian Beginnings. The Acts Seminar Report, dz. cyt., s. 123-134.

9 Por. H. Pelc, Wezwanie do metanoi w mowach Piotra według Dziejów Apostolskich, Kraków 2004, s. $127-162$.

10 Por. F. Gryglewicz, Egzegeza Dziejów Apostolskich (r. 9-12), dz. cyt., s. 150-151; H. Ordon, U progu uniwersalizmu Kościoła. Rola perykopy o chrzcie pierwszych pogan (Dz 10, 1-11, 18), [w:] Kościót w świetle Biblii, red. J. Szlaga, Lublin 1984, s. 73-81. 
bowiem oczyścił to, co Piotr uważał - zgodnie z przekazem Tory - za nieczyste, mając na uwadze pokarmy, podczas gdy widzenie odnosiło się do ludzi - pogan i Żydów. W wizji Piotra chodziło zatem o wyeksponowanie tego, że misja głoszenia Ewangelii ludziom przynależącym do politeistycznego świata, głównie grecko-rzymskiego, jest dziełem samego Boga. Wcześniej - w ujęciu Łukasza - dziełem Boga było to, że „namaścił Jezusa Duchem Świętym i mocą” i dzięki temu przeszedł On, „dobrze czyniąc”. Następnie to Bóg wskrzesił Jezusa i pozwolił Mu ukazywać się apostołom przez pewien czas $(10,40)$, po czym kazał głosić nauki, których treścią jest znaczenie Jezusa w dziejach każdego człowieka i wszystkich ludzi $(10,42)$. W końcu Bóg nie tylko Żydom, ale i poganom udzielił (gr. edoken) Ducha Świętego. To pozwoliło Piotrowi w narracji Łukasza wyprowadzić wniosek, że Bóg „nie ma względu na osoby” (10, 34), że Jemu jest przyjemny każdy człowiek, który „Go się boi i postępuje sprawiedliwie” $(10,35)$. To sprawiło, że Piotr polecił udzielić chrztu Korneliuszowi i jego domownikom. Odmowa tego byłaby sprzeciwem wobec woli Boga $(11,17)^{11}$.

Rola Piotra w akcie doprowadzenia pogan do wiary w Jezusa Chrystusa i przyjęcia do Kościoła była w ujęciu Dziejów drugorzędna. Łukasz ukazuje go jako tego, który tylko wypełnia polecenie Boga. Widać w tym nawet patos, bo i waga tego aktu nosi znamiona Bożej ingerencji, a jej skutki są dalekosiężne, gdyż wyznaczą dalsze dzieje Kościoła i zapewnią mu żywotność.

\section{Z historii badań nad perykopą}

Teologiczna interpretacja przyczyny skierowania misji głoszenia Ewangelii do pogan nie może powstrzymywać przed zadaniem pytania, kto w rzeczywistości w wymiarze historycznym przyczynił się do tego przełomu? Czy stało się to za sprawą Piotra, czy też Pawła? W poszukiwaniu odpowiedzi należy spojrzeć na interesującą nas perykopę na szerszej płaszczyźnie, poddając ją krytyce historycznej. Ona zapewne lepiej pomoże odkryć jej znaczenie.

Pouczające są w tym zakresie wcześniejsze nad nią badania ${ }^{12}$. Martin Dibelius (1956) uważał, że podłożem jej było pietystyczne opowiadanie

11 F. Gryglewicz, Egzegeza Dziejów Apostolskich (r. 9-12), dz. cyt., s. 152.

12 Por. Ewangelie i Dzieje Apostolskie, wstęp, nowy przekł. z Wulgaty, koment. przez E. Dąbrowskiego, Poznań 1961, s. 146-169; G. Schille, Die Apostelgeschichte des Lukas, Berlin 1983, s. 2-15 (Theologischer Handkommentar zum Neuen Testament, 5); J. Taylor, Dzieje Apostolskie, [w:] Międzynarodowy komentarz do Pisma Świętego. Komentarz katolicki i ekumeniczny na XXI wiek, 
o nawróceniu, analogiczne do tego z rozdziału 8 Dziejów o nawróceniu etiopskiego dworzanina, mające charakter budujący dla chrześcijan. Do owej legendy Łukasz miał dołączyć cztery dodatki: Piotrową wizję zwierząt ofiarowanych do jedzenia (10, 9-16) oraz reminiscencje do wizji (10, 27-20a), w tym dwie mowy wyjaśniające (10,34-43; 11, 5-18). Wizje przynależeć miały do odrębnych tradycji, których celem było usunięcie z praktyki chrześcijańskiej żydowskiego dziedzictwa nakazów pokarmowych związanych z kaszrut - czystością rytualną. Łukasz nadał im szersze, symboliczne znaczenie, rozciągając je na ludzi uznawanych za nieczystych (10, 28b). W ten sposób wyeksponowany epizod nawrócenia Korneliusza zyskiwał w jego księdze fundamentalne znaczenie, ponieważ uzasadniał decyzje chrześcijańskiej starszyzny jerozolimskiej opisanej w Dz 15, 6-18 ${ }^{13}$. Pogląd Dibeliusa zakwestionowano w latach 70. XX wieku (K. Loening ${ }^{14}$ ), twierdząc, że wizja Piotra należy do szerszego opowiadania, które stanowi uzasadnienie (usprawiedliwienie) dla Dz 11, 3 („,wszedłeś do ludzi nieobrzezanych i jadłeś z nimi”) i Ga 2, 12 („Zanim jeszcze nadeszli niektórzy z otoczenia Jakuba, [Piotr] brał udział w posiłkach z tymi, którzy pochodzili z pogaństwa”).

Niemało też kłopotu sprawiają mowy z perykopy o Korneliuszu. W Piotrowym przemówieniu, które zapewne jest redakcją Łukasza, widać podobieństwo do nauczania Pawłowego. Myśl o tym, że Bóg „nie ma względu na osoby" (10, 34), często występuje u Pawła (por. Ga 2, 6; Rz 2, 4; Ef 6, 9). Piotrowa mowa (10, 36-43), zwłaszcza jej początek, jest podobna do przemówienia Pawła w Antiochii Pizydyjskiej (13, 23-31). Zakończenie wskazujące na Jezusa jako sędziego odpowiada Pawłowej mowie na Areopagu w Atenach $(17,31)^{15}$. Na skutek tego perykopa podkreślająca rolę samego Boga w decyzji wprowadzenia pogan do Kościoła i rolę w tym Piotra w gruncie rzeczy legitymizuje późniejsze działanie Pawła w środowisku grecko-rzymskim. Można zatem pytać: czy to rodzaj apologii Pawła zredagowanej przez Łukasza na podstawie jakiegoś przed-Łukaszowego materiału? Zgoda wśród egzegetów panuje co do tego, że 11, 1-18 jest Łukaszowym podsumowaniem, w którym

red. nauk. wyd. oryg. W. R. Farmer, współred. S. McEvenue, A. J. Levoratti, D. L. Dungan; red. nauk. wyd. pol. W. Chrostowski, współred. T. Mieszkowski, P. Pachciarek, Warszawa 2000, s. 1369-1370.

13 M. Dibelius, Studies in the Acts of Apostles, New York 1956, s. 109-122; por. R. J. Dillon, Dzieje Apostolskie, [w:] Katolicki komentarz biblijny, red. R. E. Brown, J. A. Fitzmyer, R. E. Murphy, Warszawa 2001, s. 1213-1214.

14 K. Loening, Die Saulustradition in der Apostelgeschichte, Münster 1973, s. 95-96.

15 Por. Ewangelie i Dzieje Apostolskie, dz. cyt., s. 312-313. 
ukazuje on znaczenie nawrócenia setnika - to precedens o znaczeniu ogólnokościelnym, a nie epizod o charakterze lokalnym, związany z chrześcijańską gminą w Cezarei. Zresztą Łukasz nie objaśnia nam początków tej gminy i nie korzysta z jakiejś lokalnej tradycji, jak to czyni w odniesieniu do innych wspólnot chrześcijańskich, np. Malty, Troady (G. Schille ${ }^{16}$ ). Dla Łukasza epizod związany z Korneliuszem stanowi przygotowanie do jego wersji wydarzeń, które łączy z tzw. soborem jerozolimskim (H. Conzelmann ${ }^{17}$ ).

Dodatkowo dość zaskakująca jest paralela pomiędzy Łk 1, 5-56 (zwiastowanie Zachariaszowi, Elżbieta i jej odwiedziny przez Maryję) a Dz 10. Wskazali na nią R. Morgenthaler i J. Gewiess, a rozwiną H. Ordon ${ }^{18}$. Obok podobnych struktur literackich w nich występujących, które potwierdzałyby Łukaszową redakcję obu tekstów, spaja je wątek tematyczny - idea zbawienia, która także stanowi klamrę przenikająca Ewangelię i Dzieje Łukasza. Ono stanowi łącznik między wskazanymi perykopami - między zwiastowaniem z nawiedzeniem a epizodem Korneliusza. Dopiero perspektywa soteryczna pozwala odczytać pokrewieństwo tych oddalonych i na pozór obcych sobie perykop. Ona też pozwala rozwiązać ich strukturalne podobieństwa. Daje się ono ująć syntetycznie w stwierdzeniu: „zbawienie, które rozpoczęło się w świecie żydowskim, wychodzi poza jego granice i kieruje się do wszystkich ludzi”"19.

Z jakim przekazem mamy zatem do czynienia, gdy czytamy perykopę o Korneliuszu? Czy to Łukaszowa kompozycja literacka bazująca na wcześniejszych legendach? Czy historyczny przekaz rekonstruowany w 70-90 lat od wydarzeń, które miały miejsce w Cezarei Nadmorskiej? Czy apologia Pawła z Tarsu zredagowana przez autora Dziejów, która miała teologicznie bronić apostoła przed zarzutami, że to on bezprawnie skierował misję ewangelizacyjną do pogan, nadając jej uniwersalny charakter i zrywając z pierwotnym jej żydowskim partykularyzmem? Czy to swoista korekta obrazu Pawła, którego

16 Por. Die Apostelgeschichte, von G. Schille, dz. cyt., s. 21.

17 H. Conzelmann, Die Apostelgeschichte, wyd. 2, Tübingen 1972, s. 69. Por. T. Tułodziecki, Sobór Jerozolimski jako następstwo sporu apostolskiego w Antiochii (Dz 15, 1-35), „Biblica et Patristica Thoruniensia” 1 (2008), s. 141-160, https://doi.org/10.12775/BPTh.2008.007.

18 H. Ordon, Historiozbawcza perspektywa św. Łukasza. Struktura i teologia Łk 1, 5-56 oraz Dz 10, [w:] Chrystus i Kościót. Wybrane teksty Nowego Testamentu, red. F. Gryglewicz, Lublin 1979, s. 101-110.

19 H. Ordon, Historiozbawcza perspektywa św. Łukasza, dz. cyt., s. 109; W. Rakocy, Paweł apostoł Żydów i pogan. Łukaszowy obraz powstania i rozwoju Pawłowych wspólnot, Kraków 1997, s. 206-207. 
część gmin chrześcijańskich w początkach II wieku chciała widzieć jako jedynego apostoła (marcjonizm) ${ }^{20}$, odrzucając autorytet innych świadków?

Zanim przyjdzie odpowiedzieć na te pytania, warto przyjrzeć się ponadto trzem kwestiom szczegółowym. Najpierw uczyńmy przedmiotem zainteresowania osobę Piotra, która odgrywa w epizodzie o Korneliuszu doniosłą rolę. To z nim łączy się fundamentalną decyzję o chrzcie Korneliusza i jego domowników, w czym widzimy przełom w dziejach misji ewangelizacyjnej. Takiego znaczenia przełomowego nie ma wcześniej ani nawrócenie dworzanina królowej etiopskiej (bez udziału Piotra), ani praca ewangelizacyjna owych „hellenistów” z Jerozolimy pośród mieszkańców Samarii, ani późniejsza ich działalność w Antiochii prowadzona wśród Greków. Niemniej w świetle wcześniejszych źródeł (a są nimi listy Pawła z Tarsu), nie jest on przekonany o potrzebie zerwania z ciasnym jej pojmowaniem jako misji skierowanej do Żydów, przy jednoczesnym nakładaniu na judeochrześcijan obowiązku życia pod Torą i ścisłym jej przestrzeganiu, w tym czystości rytualnej i obrzezania. Świadectwem tego jest List do Galatów, w którym Paweł pisze:

Gdy następnie Kefas przybył do Antiochii, otwarcie mu się sprzeciwiłem, bo na to zasłużył. Zanim jeszcze nadeszli niektórzy z otoczenia Jakuba, brał udział w posiłkach z tymi, którzy pochodzili z pogaństwa. Kiedy jednak oni się zjawili, począł się usuwać i trzymać się z dala, bojąc się tych, którzy pochodzili z obrzezania. To jego nieszczere postępowanie podjęli też inni pochodzenia żydowskiego, tak że wciągnięto w to udawanie nawet Barnabę (Ga 2,11-14).

W tym kontekście opowiadanie z Dziejów o roli Piotra w przyjęciu do wspólnoty chrześcijańskiej Korneliusza oraz jego tłumaczenie przed starszyzną jerozolimską z faktu spożywania pokarmów razem z poganami, w czym naruszał Torę (Kpł 11), wydaje się niespójne. Już blisko sześćdziesiąt lat temu E. Dąbrowski, rozważając tę kwestię, pisał:

Nikt oczywiście nie zaprzecza niejednokrotnie ingerencji Łukasza w opracowanie dostępnych mu źródeł, ale trzeba by zapomnieć o naczelnych zasadach jego pisarstwa, aby utrzymywać, że ingerencję swoją posunął on do stwarzania fikcyjnych wydarzeń w służbie swej teologii. ${ }^{21}$

20 K. Pilarczyk, Wokót problemu datacji Dziejów Apostolskich, dz. cyt., s. 86.

21 Ewangelie i Dzieje Apostolskie, dz. cyt., s. 314. 
Część współczesnych egzegetów uważa jednak, że Łukasz podretuszował w tym momencie dzieje misji ewangelizacyjnej, wprowadzając Piotra w miejsce Pawła, w czym zapewnił swojej księdze jedność kompozycyjną i teologiczną. Łukasz nie zmienił istoty jej przebiegu, tylko jej głównych ludzkich bohaterów. Ale czy te detale historyczne miały dla niego aż takie znaczenie? Może bardziej mu chodziło o podkreślenie ingerencji samego Boga w dzieje Kościoła i przydanie przełomowemu zwrotowi w jego misji autorytetu samego Piotra - najważniejszej osoby spośród martyres.

Drugi szczegół dotyczy Korneliusza. Łukasz ukazuje go jako setnika „kohorty italskiej” stacjonującej w Cezarei, mieście portowym zbudowanym przez Heroda Wielkiego, zamieszkiwanym przez licznych pogan, w tym prokuratorów rzymskich, i dlatego później zwanego pogardliwie w źródłach rabinicznych „córą Edomu”22. Otóż w czasie, gdy miały się rozegrać wydarzenia w domu Korneliusza, a jest to około 36-37 roku, jak wynika z chronologii Dziejów, zaledwie kilka lat po nawróceniu Pawła, żołnierze rzymscy nie mogli prawdopodobnie stacjonować w Cezarei za życia Heroda Agryppy I (zmarłego w 44 roku po Chrystusie). Łukaszowa wzmianka o kohorcie italskiej wydaje się anachronizmem. Jej obecność w źródłach poświadczona jest dopiero od 69 do $157 \mathrm{roku}^{23}$. Zdawałoby się, że w te późniejsze realia historyczne wpisuje Łukasz epizod Korneliusza, nie przywiązując do tego szczególnej uwagi. Również cechy Korneliusza odpowiadają charakterystyce pobożnego setnika z Kafarnaum (Łk 7, 4-5). Czy to zatem „typowy” poganin, na dodatek żołnierz, który zaliczany jest do „bojących się Boga” (gr. fobumenoi ton theon) ${ }^{24}$, sympatyzujący z synagogą, stosujący się do żydowskich praktyk (modlitwy i jałmużny)?

Niewiele możemy powiedzieć o początkach dziejów gminy chrześcijańskiej w Cezarei, ale nawet w Historii Kościoła metropolity Cezarei Euzebiusza nie znajdujemy o nim wzmianki. Stąd też przekonanie Hieronima o tym, że nawrócony Korneliusz stał się założycielem złożonego z pogan Kościoła Cezarei (Adversus Jovinianum, 1, 39) i zapis w Konstytucjach apostolskich $(7,46)$ o Korneliuszu, drugim biskupie tego miasta, są wyraźnie legendarne (E. Dąbrowski). Dlatego można pytać, czy Korneliusz nie jest swoistym

22 H. L. Strack, P. B. Billerbeck, Kommentar zum Neuen Testament aus Talmud und Midrasch, t. 2: Das Evangelium nach Markus, Lukas und Johannes und die Apostelgeschichte, München 1969, s. 688.

23 Por. Z. Rostkowski, Kontekst historyczny cezarejskiej mowy Piotra (Dz 10, 34-43), „Studia Teologiczne” 16 (1998), s. 31-34; Ewangelie i Dzieje Apostolskie, dz. cyt., s. 308-309.

24 Ewangelie i Dzieje Apostolskie, dz. cyt., s. 316-321. 
„eponimem” chrześcijańskim, którego historyczności nie sposób potwierdzić, wprowadzonym do etiologicznego opowiadania Łukasza, które ma wyjaśnić, jak doszło do przekierowania misji ewangelizacyjnej z Żydów także na pogan? Adresaci Dziejów sami żyją już w rzeczywistości jej trwania i dalszego prowadzenia. Teraz ich autor nie tyle próbuje opisać jej historyczne początki, lecz uzasadnić je teologicznie, aby drugie i trzecie pokolenie -już etnochrześcijan, ale także judeochrześcijan - postrzegało ją nie jako dzieło Pawła z Tarsu czy nawet Piotra, lecz realizację Bożego planu przypieczętowanego autorytetem apostołów, w tym samego Piotra, w który później wpisze się Paweł ze swoją działalnością misyjną. W ujęciu teologicznym Łukasza ów plan jest jasny. Zbawienie dokonało się przez Jezusa Chrystusa i dokonuje się nadal dzięki wylaniu Ducha Świętego. Najpierw doświadczyli tego Żydzi, co Łukasz ujął w opowiadaniu zawartym w drugim rozdziale Dziejów, a następnie poganie (epizod o Korneliuszu to tzw. „pięćdziesiątnica pogan” lub „drugie zesłanie Ducha Świętego”25). Jedni i drudzy przyjęli słowo Boże, nawrócili się oraz uwierzyli w Jezusa Chrystusa.

W końcu trzecia kwestia historyczna związana z perykopą o Korneliuszu związana jest z pierwszą wizją Piotra, która niedwuznacznie próbuje zniwelować żydowską zasadę podziału pokarmów na czyste i nieczyste oraz praktykę rozdziału, w tym zakazu wspólnych posiłków, pomiędzy Żydami a nie-Żydami ${ }^{26}$. We współczesnych badaniach (D. E. Smith, J. B. Tyson) wysuwa się zastrzeżenia co do tego, czy w dekadę lub dwie po wydarzeniach paschalnych Jezusa mogły być one przez judeochrześcijan tak jednoznacznie wprowadzone i stosowane, jak ma to zapewne miejsce w czasach powstawania Dziejów Apostolskich (przełom pierwszej i drugiej dekady II wieku) ${ }^{27}$. Wygląda na to, że w analizowanej perykopie mamy do czynienia z kolejnym anachronizmem.

\section{Stare dylematy i nowe propozycje rozwiązań}

Konkludując, należy zapytać, czy perykopa o Korneliuszu to zatem mit założycielski chrześcijańskiej misji wśród pogan? Wielu współczesnych uczonych

25 T. Siuda, Duch Święty w Dziejach Apostolskich, [w:] Księga Dziejów Apostolskich, red. J. K. Pytel, Szczecin 1999, s. 321-323.

26 Z. Rostkowski, Kontekst historyczny cezarejskiej mowy Piotra (Dz 10, 34-43), dz. cyt., s. 27-28.

27 Acts and Christian Beginnings. The Acts Seminar Report, dz. cyt., s. 131-134. 
badających starożytną literaturę dąży do rozróżniania w niej historii od mitu. Zazwyczaj wczesne teksty chrześcijańskie postrzegane są przez nich jako mityczne ${ }^{28}$. Dlatego uważają, że pierwotne chrześcijaństwo nie może być rozpoznawane przez Dzieje jako źródło historyczne, jak to czyniło i czyni do dzisiaj wielu historyków, ponieważ opisują one jego powstanie jako mit założycielski Kościoła. Jednocześnie nie wykluczają, że w tym przekazie mitycznym nie ma elementów historycznych. Narracje w Dziejach, mimo że dominują w nich tematy niehistoryczne, mogą zawierać, co należy z naciskiem podkreślić, wiele materiałów historycznych pochodzących z wcześniejszych źródeł czy tradycji opartych na historycznych wspomnieniach. To prowadzi do jednego z najtrudniejszych problemów związanych z badaniami nad Dziejami, tj. umiejętnością rozdzielania tego, co w nich jest historyczne, od tego co mityczne. Jednocześnie nie należy deprecjonować mitycznej ich warstwy dotyczącej powstania chrześcijaństwa, lecz umiejętnie ją czytać, posługując się współczesnymi teoriami mitu. Biorąc pod uwagę preferowaną późną datę powstania Dziejów (początek II wieku), możemy w nich odnaleźć dużo więcej przekazu o dziejach chrześcijaństwa, w tym także początków drugiego stulecia.

Dostrzega się w Dziejach całkowite novum w tym, że ich autor powiązał warstwę nadprzyrodzoną, zbawczą z warstwą doczesną i empiryczną bez mieszania ich i bez rozrywania całkowitego, a w warstwie doczesnej zastosował rodzaj wyjaśnienia przez przyczyny. U Łukasza każde wydarzenie $\mathrm{z}$ historii zbawienia, w tym skierowanie misji ewangelizacyjnej do pogan, jest dwuwymiarowe: naturalne i zarazem nadprzyrodzone, doczesne i zarazem zbawcze, o wymiarze historycznym i wiecznym, bez utożsamiania wewnętrznego jednego porządku z drugim ${ }^{29}$. Autor Dziejów dał początek nowemu - nie bałbym się powiedzieć - mitycznemu obrazowi dziejów, w które wkroczył Chrystus i zaistniał Kościół wśród pogan. Nazwanie tego obrazu mitycznym nie powinno budzić obaw. Można w tym widzieć sposób prowadzący do uogólnienia i wykładania faktów historycznych. Taką drogą poszedł autor Dziejów. Punktem wyjścia dla niego były misteria jako fakty: zaistnienie wspólnot kościelnych, pierwsze ich chwile pośród Żydów i pogan, znoszone prześladowania, nawrócenia. Pod tymi faktami w szacie empirycznej Łukasz widział

28 Por. L. H. Martin, History, Historiography, and Christian Origins. The Jerusalem Community, [w:] Redescribing Christian Origins, ed. R. Cameron and M. P. Miller, Atlanta 2004, s. 263-273; G. Lüdemann, The Acts of Apostles. What Really Happened in the Earliest Days of the Church, Amhest, NY 2005.

29 Por. C. S. Bartnik, Historiologia w kulturach starożytnych, Lublin 2000, s. 255. 
gesta Dei-działanie Boże. Dla niego wydarzenia empiryczne są realistyczne, ale jednocześnie tworzą historię sakralną, bo mają swój wymiar i sens Boży oraz wpisują się w odwieczny Boży plan. Stają się przez to wydarzeniami misteryjnymi, a nie pozostają "gołe” jak naturalne, wprowadzają one w świat sakralny. Medium łączącym to, co empiryczne, z tym, co pozaempiryczne stanowi głównie słowo. Dlatego przekaz religijny w Dziejach, w tym perykopie o Korneliuszu, opiera się na naocznych świadkach i sługach słowa (Łk 1, 2). W porządku naturalnym nie można tłumaczyć rzeczy przez słowo, lecz przez drugą rzecz. Niemniej w porządku metafizycznym i sakralnym (Bożym) słowo wyjaśnia rzecz. W odniesieniu do Dziejów tym słowem jest słowo Boże. Dlatego powstanie oraz początki Kościoła w wymiarze najwyższym tłumaczy się poprzez Boga „mówiącego”30. Nie dziwi nas zatem, że w Lukanach obrazowanie początków Kościoła rozpoczyna się od faktów i prowadzi do misterium oraz szeroko kreślonego całościowego planu Bożego ${ }^{31}$. W takim ujęciu słowo nie jest tylko, nawet w historiografii, pustą pamięcią, wyłącznie narzędziem komunikacji, lecz przynależy do języka, który - za Johnem Langshawem Austinem - należy nazwać performatywnym ${ }^{32}$. Ta kategoria może dobrze służyć do opisu specyfiki dzieła Łukasza, napisanego głównie dla chrześcijan nie po to, aby było jedynie opowiadaniem o przeszłości Kościoła, ale wprowadzeniem w jego rzeczywistość. Jego zadaniem nie jest informowanie czytelnika, lecz przede wszystkim formowanie ${ }^{33}$. Owa rzeczywistość to nic innego jak transcendentny wymiar świata religijnego, który swoją realność uzyskuje w rytualnym (sakramentalnym, kultowym, misteryjnym) „dzianiu się” mitu $^{34}$. Przywoływanie go pozwala człowiekowi religijnemu partycypować w świętych wydarzeniach i jednocześnie odczuwać przemożną realność tych

30 Tamże, s. 255-256.

31 Zob. G. Vermes, Twarze Jezusa, przekł. J. Kołak, Kraków 2008, s. 161-167.

32 Zob. J. L. Austin, Mówienie i poznawanie. Rozprawy i wykłady filozoficzne, przeł., wstępem i przypisami opatrzył oraz skorowidze sporządził B. Chwedeńczuk, przekł. przejrz. J. Woleński, Warszawa 1993. Chodzi o język, który nie jest tylko szczególnym aktem mowy (coś opisuje), ale także działania (oddziałuje na rzeczywistość).

33 Por. K. Backhaus, Lukas der Maler. Die Apostelgeschichte als intentionale Geschichte der christlichen Erstepoche, [w:] K. Backhaus, G. Häfner, Historiographie und funktionales Erzählen. Zur Konstruktivität in Gechichtstheorie und Exegese, Neukirchen-Vluyn 2007, s. 47. W polskiej literaturze Andrzej J. Najda nie nazywa języka Dziejów performatywnym, lecz historyczno-paradygmatycznym, a samą księgę zalicza do historiografii paradygmatycznej - por. A. J. Najda, Historiografia paradygmatyczna w Dziejach Apostolskich, Warszawa 2011 (Rozprawy i Studia Biblijne, 39).

34 Por. S. Sztajer, Mit - język - rzeczywistość. Mityczno-rytualna kreacja i odtwarzanie uniwersum religijnego, „Przegląd Religioznawczy” 2006 nr 1 (219), s. 77. 
wydarzeń. Na tym polega istota mitu Łukaszowego: nie ma w nim zgodności z pewną zaszłą i transcendentną rzeczywistością, nie mówi on, że „prawdą jest, że było tak i tak”, że misja wśród pogan miała taki, a nie inny przebieg, ale angażuje jednostki w przebieg odtwarzanej świętej historii. Istota mitu polega raczej na możliwości uczestniczenia w rzeczywistości niż detalicznym jej odzwierciedleniu, choć bez odrywania od rzeczywistości gwarantowanej świadectwem autoptoi, a jeszcze lepiej martyres, jak w przypadku perykopy o Korneliuszu (tym różni się od mitów gnostyckich). Mit odgrywa zasadniczą rolę nie tylko w legitymizacji chrześcijańskiego porządku społecznego, w opisie wcześniejszego świata religijnego, lecz przede wszystkim w ustanawianiu obecnego świata religijnego i widzeniu go jako całości (universum). Jeszcze precyzyjniej sformułuje to G. van der Leeuw, dla którego mit nie jest spekulacją, wyjaśnieniem czy interpretacją świata religijnego, lecz przeżywaną realnością ${ }^{35}$, w tym prowadzonej misji ewangelizacyjnej wśród pogan, która wpisana jest w Boży plan zbawienia.

\section{Abstrakt}

\section{„Pięćdziesiątnica pogan” w ujęciu Dziejów Apostolskich (Dz 10, 1-11, 18). Casus Korneliusza i jego domu}

Badanie początków chrześcijaństwa metodą historyczną sprawia dużo trudności, głównie z powodu znikomej ilości źródeł. Do jednych z najciekawszych należy kanoniczna księga Dziejów Apostolskich, która w Nowym Testamencie jest unicum tak pod względem genologicznym, jak i treściowym. Dostarcza ona dość szczególnego obrazu powstania i rozwoju Kościoła. Autor artykułu pyta, jaki to obraz - historyczny, mityczny, teologiczny czy teologiczno-polemiczny? W badaniach koncentruje się na jednym tylko wątku ukazanym w tej księdze, to jest na przełomowym dla dziejów misji ewangelizacyjnej skierowaniu jej od pogan. Najpierw sytuuje interesującą go perykopę w koncepcji całej księgi, a następnie przypomina w skrócie historię jej egzegezy oraz poddaje ją krytyce historycznej, by w końcu odkryć w niej ważną kartę mitu wczesnochrześcijańskiego. Nie negując jego historycznego zakorzenienia, wskazuje na teologiczne jej przesłanie niezwykle ważne dla społeczności chrześcijan z początku drugiego wieku.

Słowa kluczowe: Nowy Testament; Dzieje Apostolskie; św. Łukasz; chrzest; historia chrześcijaństwa; mit

35 Por. G. van der Leeuw, Fenomenologia religii, z niem. przeł. i wstępem opatrzył J. Prokopiuk, Warszawa 1997, s. 364. 


\section{Abstract}

\section{The "Pentecost of the Gentiles" as Presented in the Acts of the Apostles (Acts $10: 1-11: 18)$ : The Case of Cornelius and His Home}

Research on the beginnings of Christianity using the historical method brings about many difficulties, mainly due to the scarcity of sources. One of the most interesting is the canonical book of the Acts of the Apostles, which is unique among the New Testament books, also with regards to genology and its content. It provides us with a unique image of the beginnings and growth of the Church. The author asks if this is a historical, mythical, theological, or theological-polemical image. In his research, he focuses on only one theme presented in this book: the historical watershed moment of directing the mission of evangelization towards the pagans. First, he situates the pericope in question in the conception of the entire book. Next, he summarizes the history of its exegesis and subjects it to historical criticism, finally finding within it an important chapter of early Christian mythology. While not negating its historical roots, he notes its theological message, which was especially important for the Christian community of the early second century.

Keywords: New Testament; Acts of the Apostles; St. Luke; baptism; history of Christianity; myth

\section{References}

Austin, J. L. (1993). Mówienie i poznawanie. Rozprawy i wykłady filozoficzne. (J. Woleński, Ed., B. Chwedeńczuk, Trans.). Warszawa: Wydawnictwo Naukowe PWN.

Backhaus, K. (2007). Lukas der Maler. Die Apostelgeschichte als intentionale Geschichte der christlichen

Erstepoche. In K. Backhaus \& G. Häfner (Eds.), Historiographie und fiktionales Erzählen. Zur Konstruktivität

in Geschichtstheorie und Exegese (pp. 30-66). Neukirchen-Vluyn: Ludwig-Maximilians-Universität München.

Bartnik, C. S. (2000). Historiologia w kulturach starożytnych. Lublin: Standruk.

Bruce, F. F. (1999). Dzieje apostolskie. B. M. Metzger, M. D. Coogan, W. Chrostowski, \& B. Geller Nathanson (Eds.),

A. Karpowicz (Trans.), Stownik wiedzy biblijnej (3rd ed., pp. 128-132). Warszawa: Vocatio.

Bultmann, R. K. (1958). Jesus Christ and mythology. New York: Scribner.

Conzelmann, H. (1972). Die Apostelgeschichte (2nd ed.). Tübingen: Mohr.

Dąbrowski, E. (Ed.). (1961). Ewangelie i Dzieje Apostolskie (14th ed.). Poznań: Księgarnia św. Wojciecha.

Dibelius, M. (1956). Studies in the Acts of the Apostles. New York.

Dillon, R. J. (2001). Dzieje Apostolskie. In R. E. Brown, J. A. Fitzmyer, R. E. Murphy, \& W. Chrostowski (Eds.),

K. Bardski (Trans.), Katolicki komentarz biblijny (pp. 1177-1250). Warszawa: Vocatio.

Ehrman, B. D. (2014). Nowy Testament. Historyczne wprowadzenie do literatury wczesnochrześcjańskiej. (S. Tokariew,

Trans.). Warszawa: Wydawnictwo CiS.

Gryglewicz, F. (1982). Egzegeza Dziejów Apostolskich (r. 9-12). In L. Stachowiak \& R. Rubinkiewicz (Eds.), Materiaty

pomocnicze do wykładów z biblistyki (Vol. 5, pp. 135-161). Lublin: Redakcja Wydawnictw KUL.

Gryglewicz, F. (1986). Teologia Dziejów Apostolskich listów katolickich i pism św. Jana Ewangelisty. Lublin: Redakcja Wydawnictw KUL.

Leeuw, G. van der. (1997). Fenomenologia religii. (J. Prokopiuk, Trans.) (2nd ed.). Warszawa: Książka i Wiedza. Loening, K. (1973). Die Saulustradition in der Apostelgeschichte. Münster: Verlag Aschendorff.

Lüdemann, G. (2005). The Acts of the Apostles. What really happened in the earliest days of the church. Amherst, NY: Prometheus Books.

Martin, L. H. (2004). History, Historiography, and Christian Origins. The Jerusalem Community. In R. Cameron \& M. P. Miller (Eds.), Redescribing Christian origins (pp. 263-273). Atlanta: Society of Biblical Literature. 
Najda, A. J. (2011). Historiografia paradygmatyczna w Dziejach Apostolskich. Warszawa: Vocatio.

Ordon, H. (1979). Historiozbawcza perspektywa św. Łukasza. Struktura i teologia Łk 1, 5-56 oraz Dz 10. In F. Gryglewicz (Ed.), Chrystus i Kościót. Wybrane teksty Nowego Testamentu (pp. 101-110). Lublin: Redakcja Wydawnictw KUL.

Ordon, H. (1984). U progu uniwersalizmu Kościoła. Rola perykopy o chrzcie pierwszych pogan (Dz 10, 1-11, 18). In J. B. Szlaga (Ed.), Kościół w świetle Biblii (pp. 73-81). Lublin: Wydawnictwo Towarzystwa Naukowego Katolickiego Uniwersytetu Lubelskiego.

Pelc, H. (2004). Wezwanie do metanoi w mowach Piotra według Dziejów Apostolskich. Kraków: Wydawnictwo Naukowe PAT.

Pilarczyk, K. (2003). Literatura wczesnochrześcijańska. In Starożytność (pp. 539-581). Bochnia-Kraków: Prowincjonalna Oficyna Wydawnicza, SMS

Pilarczyk, K. (2015). Wokół problemu datacji Dziejów Apostolskich. Wrocławski Przegląd Teologiczny, 23(2), 75-94. Ptaszek, R. T. (2000). Bultmann Rudolf. In M. A. Krapiec, A. Maryniarczyk, \& M. Czachorowski (Eds.), Powszechna encyklopedia filozofii (Vol. 1, pp. 735-737). Lublin: Polskie Towarzystwo Tomasza z Akwinu.

Rakocy, W. (1997). „Będziecie moimi świadkami...” (Dz 1, 8) (Dzieje Apostolskie). In A. S. Jasiński (Ed.), Dzieje Apostolskie. Listy św. Pawła (pp. 42-47). Warszawa: Akademia Teologii Katolickiej.

Rakocy, Waldemar. (1997). Paweł apostoł Żydów i pogan. Łukaszowy obraz powstania i rozwoju Pawłowych wspólnot. Kraków: Instytut Teologiczny Księży Misjonarzy.

Rostkowski, Z. (1998). Kontekst historyczny cezarejskiej mowy Piotra (Dz 10, 34-43). Studia Teologiczne, 16, $23-41$. Schille, G. (1983). Die Apostelgeschichte des Lukas (1st ed.). Berlin: Evangelische Verlagsanstalt.

Siuda, T. (1999). Duch Święty w Dziejach Apostolskich. In J. K. Pytel (Ed.), Księga Dziejów Apostolskich (pp. 321-323). Szczecin: Ottonianum.

Smith, D. E., \& Tyson, J. B. (Eds.). (2013). Acts and Christian beginnings: the Acts Seminar report. Salem, Oregon: Polebridge Press.

Strack, H. L., \& Billerbeck, P. (1969). Kommentar zum Neuen Testament aus Talmud und Midrasch. Bd. 2. Das Evangelium nach Markus, Lukas und Johannes und die Apostelgeschichte (5th ed.). München: Beck.

Sztajer, S. (2006). Mit - język - rzeczywistość. Mityczno-rytualna kreacja i odtwarzanie uniwersum religijnego. Przeglad Religioznawczy, (1), 59-82.

Taylor, J. (2000). Dzieje Apostolskie. In W. R. Farmer, S. E. McEvenue, A. J. Levoratti, D. L. Dungan, W. Chrostowski, T. Mieszkowski, \& P. Pachciarek (Eds.), Międzynarodowy komentarz do Pisma Świętego. Komentarz katolicki i ekumeniczny na XXI wiek (pp. 1367-1403). Warszawa: Verbinum.

Tułodziecki, T. (2008). Sobór Jerozolimski jako następstwo sporu apostolskiego w Antiochii (Dz 15, 1-35). Biblica et Patristica Thoruniensia, 1, 141-162. https://doi.org/10.12775/BPTh.2008.007

Tyson, J. B. (2007). Acts - A Myth of Christian Origins. Forum Third Series, 1(2), 171-189.

Tyson, J. B. (2013). Acts, Myth, and History. In D. E. Smith \& J. B. Tyson (Eds.), Acts and Christian beginnings: the Acts Seminar report (pp. 15-19). Salem, Oregon: Polebridge Press. 